\title{
BUSINESS SUCCESS AND BUSINESSES' BEAUTY CAPITAL
}

Ciska M. Bosman

Gerard A. Pfann

Jeff E. Biddle

Daniel S. Hamermesh

Working Paper 6083

\section{NATIONAL BUREAU OF ECONOMIC RESEARCH 1050 Massachusetts Avenue Cambridge, MA 02138 July 1997}

Steve Bronars and Steve Nickell provided helpful suggestions, as did participants in seminars at several universities. We thank several individuals in the Dutch advertising industry for their assistance, and are deeply grateful to the six people who evaluated the photographs that form much of the basis for this study. This paper is part of NBER's research program in Labor Studies. Any opinions expressed are those of the authors and not those of the National Bureau of Economic Research.

(C) 1997 by Ciska M. Bosman, Gerard A. Pfann, Jeff E. Biddle and Daniel S. Hamermesh. All rights reserved. Short sections of text, not to exceed two paragraphs, may be quoted without explicit permission provided that full credit, including $\mathbb{C}$ notice, is given to the source. 
Business Success and Businesses' Beauty Capital

Ciska M. Bosman, Gerard A. Pfann, Jeff E. Biddle

and Daniel S. Hamermesh

NBER Working Paper No. 6083

July 1997

JEL No. J71

Labor Studies

\begin{abstract}
We examine whether a difference in pay for beauty is supported by different productivity of people according to looks. Using a sample of advertising firms, we find that those firms with betterlooking executives have higher revenues and faster growth than do otherwise identical firms whose executives are not so good-looking. The impact on revenue far exceeds the likely effect of beauty on the executives' wages. This suggests that their beauty creates firm-specific investments, in the form of improved relationships within work groups, the returns to which are shared by the firm and the executive.
\end{abstract}

Ciska M. Bosman

Faculty of Economic Sciences

Maastricht University

6200 Maastricht

THE NETHERLANDS

Jeff E. Biddle

Department of Economics

Michigan State University

East Lansing, MI 48824-1038
Gerard A. Pfann

Faculty of Economic Sciences

Maastrict University

6200 Maastricht

THE NETHERLANDS

Daniel S. Hamermesh

Department of Economics

University of Texas

Austin, TX 78712-1173

and NBER

hamermes@eco.utexas.edu 
Recent research has demonstrated a relationship between physical attractiveness and earnings for workers generally. ${ }^{1}$ In the case of attractiveness (and other ascriptive characteristics too) the extent to which wage differentials are due to discrimination rather than to differences in productivity remains an open question. One way of examining this issue is to study the payoff to the characteristic in product markets. If we find none, that would cast serious doubt on interpreting any finding of a positive impact of beauty on earnings as resulting from its effects on productivity, since nondiscriminating employers will not pay for beauty unless it adds to their revenues or is bundled with some unobservable characteristic that increases the firm's value. As with other ascriptive characteristics such as sex and race, the extent to which the wage differentials associated with beauty are due to differentials in productivity rather than some form of employer discrimination requires careful analysis of estimates of production- or revenue-functions and is at this point a completely open question.

This study uses firm-level panel data from the Dutch advertising industry to analyze the effect of employees' attractiveness, or beauty, on firms' performance. In Section I we discuss how and why beauty might be expected to affect firms' performance, particularly in the market for advertising, and we provide the theoretical motivation for the subsequent empirical analysis. In Section II we describe the data to be used in the analysis, both the directly available data on advertising firms in the Netherlands and the measures of employee beauty that we construct. In Section III we report results on the relationship between our beauty measures and firms' revenues, including both standard and fixed-effects estimates of the impact of beauty. In Section IV we analyze the effect of beauty on firm growth, and Section V presents the general implications of our findings. 


\section{Theoretical Issues}

There are a number of reasons why a relationship might exist between the physical attractiveness of a firm's employees and the performance of the firm. In industries where clients have substantial interactions with employees, consumer discrimination might give a competitive advantage to firms with more attractive workers. At first glance a consumer discrimination model would seem to be applicable in the case of advertising. The advertising business involves considerable direct contact between agency employees and clients, and both appearance and physical attractiveness are important considerations in the design of the advertising product. People in the industry believe that the actual choice of an advertising agency by a client is influenced by ascriptive factors (FHV/BBDO, 1983), which might include the beauty of the agency's employees. The consumers of the product sold by advertising agencies are, however, firms. If these businesses are assumed to operate in competitive markets, they could not pay to indulge their managers' unproductive tastes for dealing with attractive people and still survive in a long-run equilibrium.

If the assumption of competitive markets for ad agencies and their clients is maintained, there must be some real effect of employee beauty on the production process of the advertising agency for a beauty/firm performance relationship to exist. One could assume that, like human capital in the form of formal education (e.g., Welch, 1970), the "beauty capital" of a firm augments its production function, as in $Y=f(N, K, B), Y_{B}>0$, where $Y$ is a measure of value added or sales, $N$ is the number of employees, $\mathrm{K}$ the level of physical capital , and $\mathrm{B}$ is beauty capital, some function of the physical appearance of all or certain key employees. Firms would then choose $N, K$ and $B$ to maximize profits:

(1) $\pi=\mathrm{PY}-\mathrm{C}(\mathrm{N}, \mathrm{K}, \mathrm{B})$, 
where $P$ is the price of advertising and $\mathrm{C}(\cdot)$ is a cost function, with the dependence of $\mathrm{C}$ on $\mathrm{B}$ reflecting the higher wages that more attractive workers would command, given the productivity of beauty. This could lead to a long-run competitive equilibrium in which all firms earned zero profits, but firms with more beauty capital produced more, holding $\mathrm{N}$ and $\mathrm{K}$ constant, and thus obtained higher revenues. Under these circumstances data on output or revenue could be regressed on a measure of beauty capital as well other firm inputs and characteristics, with the coefficient on beauty estimating the impact of beauty in the firm's production function.

Alternatively, one might assume that an increase in beauty capital, instead of allowing the production of more units of advertising using the same inputs, allowed the production of a higherquality product that commanded a higher price in the marketplace. ${ }^{2}$ Firms would then maximize:

$$
\pi=\mathrm{P}(\mathrm{Q}(\mathrm{B})) \cdot \mathrm{Y}(\mathrm{N}, \mathrm{K})-\mathrm{C}(\mathrm{N}, \mathrm{K}, \mathrm{B}),
$$

where $Q$ denotes the quality of the advertising produced, which depends positively on $B$. This would generate a long-run zero-profit equilibrium in which firms with more beautiful employees sold higherquality advertising at higher prices, but incurred higher labor costs as a result of the premium wages that they paid to more attractive workers. In this case the coefficient of a variable measuring beauty capital in a regression describing revenue would represent a combination of the technological relationship between beauty capital and the quality of the product, and the demand-side relationship between quality and product price.

Arguably, either of these cases might exist in the advertising industry or in other industries. Research in sociology and social psychology has produced evidence that attractive people tend to be more socially skilled than unattractive people, adopting different and often more effective styles of social interaction. ${ }^{3}$ Other studies have also shown that, holding constant the message, people are 
more likely to be persuaded by and to agree with the ideas expressed by a more attractive person. (Bull and Rumsey, 1988, pp. 41-50, 253-58; Hatfield and Sprecher, 1986, pp. 256-63.) It seems plausible that, other things equal, a manager who is better able to persuade and build consensus among a group of employees would contribute to greater productivity in a number of settings. Certainly in advertising, where interpersonal interaction and teamwork are important parts of the production process, it is reasonable to assume that managers with greater social skills could elicit more and/or better work from their subordinates. Such intrafirm social capital is different, but in many ways similar to the social capital that has been studied by, inter alia, Burt (1992).

In the competitive situations outlined above all firms earn equal profits in long-run equilibrium, and the more beautiful workers can capture the full returns to their greater productivity. There are reasons to believe, however, that if more attractive workers are more productive we will observe a relationship between the beauty of the firm's employees and measures of the firm's performance beyond revenue, such as growth and profitability. First, there is evidence of a relationship between managerial ability and firm profitability. For example, Johnson et al (1985) show that the price of a company's stock reacts to the surprise death of the company's CEO, while Warner et al (1988) find that the stock market reacts to changes in top management.

Second, models of competitive labor markets that include search costs, human capital investment, or simply worker and firm heterogeneity often predict the existence of quasi-rents to labor, some of which can be captured in the short run by the firm. If the quasi-rents are increasing in ability, the firm's profits, and thus its ability to expand and to survive adverse shocks, may be increased as well. Hashimoto (1981) and Hashimoto and Yu (1980), for example, formalize Becker's (1964) insight that the worker and firm will share the quasi-rents generated by specific human-capital 
investments. They show that if the return to specific human capital is subject to shocks during the employment relationship, and that either information problems or contracting costs prevent wages from adjusting to those shocks, the sharing parameter characterizing the optimal contract between worker and firm will be unrelated to the amount and the marginal cost of the specific investment. More productive workers will thus end up generating more quasi-rents for the firm.

We have argued that more attractive workers may be more productive because of their greater social skills that facilitate productive interactions with subordinates and clients. Without delving into the determinants of the optimal amount of such an investment, we can infer that good working relationships with one's coworkers and the firm's clients creates a form of firm-specific human capital; and a facility for forming these good relationships can be viewed as lowering the marginal cost of acquiring such capital. In the context of Hashimoto's model, then, the more attractive manager invests more in the development of such relationships, thus generating higher earnings for himself and higher quasi-rents for his employer.

One might argue that workers are aware of their looks, so that employers would have to attract them by paying the average of the extra revenue that workers of their beauty are expected to generate. This assumes that employers can assess fully the contribution of a particular worker in their workplace ex ante, and that employers are risk neutral. Both assumptions are probably wrong, and the same arguments that generate outcomes in the theory of statistical discrimination ensure that beautiful workers will enter the firm at a wage below the annuitized value of the expected contributions of their beauty to revenue. Another argument is that the beautiful manager can appropriate all the quasi-rents the beauty generated by forming, or threatening to form a new firm with his or her team. This is true, and the departure of groups of workers from existing firms is the 
most common source of the formation of new firms in this industry; but uncertainty about the willingness of other workers to depart for the proposed new firm limits this threat and again reduces the problem to one of workers and firms bargaining over the quasi-rents generated by the worker's beauty.

Finally, the Dutch advertising firms that are the focus of the empirical work tend to be small, with managerial discretion resting with an executive board of managers. It is the attractiveness of these board members that forms the basis for our measures of firm beauty capital. Many of these board members have equity stakes in their firms, and even if competitive forces allowed them to capture the full returns to their attractiveness, they could choose to take part of their compensation in the form of an increased equity value of the firm. Because we do not have information on the equity value of the firms in our study, in the empirical work we thus also relate measures of executives' beauty to measures of firm growth.

\section{Measuring Beauty Capital and Other Characteristics}

An advertising agency enters our sample when it is or becomes a member of one of the associations of Dutch advertising agencies (Rota, VEA or Pragma) and is consequently included in Adformatie Bijlagen, annual listings of the most important agencies in the Netherlands. ${ }^{4}$ We include a firm in the first year during the period 1984-94 that it is reported in this publication. Our sample consists of 289 advertising agencies, not all of which are in the sample for all eleven years, yielding $2111(\mathrm{~N}(\mathrm{t}) \mathrm{xT})$ observations. $\mathrm{N}(\mathrm{t})$ varies from 162 to 222 , with an average of 191 firms per year. The dynamism that characterizes the advertising industry is reflected in the sample: About 35 percent of the firms (101 agencies) enter the sample after 1984, and 29 percent ( 83 agencies) exit before 1995. 
Because of the method we used to generate the data, inclusion in the sample indicates a qualitatively and financially healthy organization. The selection method produces a sample that consists of larger and more established organizations. Industry experts assure us that nearly all agencies of a reasonable size are captured by the selection criteria. Indeed, the agencies that we include account for about 70 percent of industry sales.

The beauty of the firms' executives was assessed on the basis of photographs (black-andwhite head-and-shoulders pictures) collected from industry yearbooks in which several of the characteristics of the agencies and pictures of their board members (executives) are presented (the Adformatie Bijlagen and the Blauwe Burogidsen). Pictures of most of the agencies' executives are published: The mean number of pictures is 2.71 , the mean number of board members is 2.80 . The few losses are concentrated disproportionately among the very few largest firms ( 9 or more board members) and presumably are of lower-level members of the management team at those agencies.

The photographs were rated independently by six individuals: Two men and one woman forty or older, and two men and one woman under forty. This choice of the Dutch raters is designed to reflect the age-sex make-up of the firms' clientele. The same six raters examined all available photographs. Each rater was asked to assign each picture a value between 5 and 1 , representing the physical attractiveness of the photographed person. The scale assigned a rating (in Dutch) of 5 , strikingly handsome or beautiful; 4 , above-average attractiveness; 3 , average beauty; 2 , plain, below average in attractiveness; or 1 , homely, far below average in attractiveness. ${ }^{6}$ Since the ages of the top managers differ widely, the raters were instructed to control for age when assessing the attractiveness of each individual. They were also told to account for particularly unflattering poses or expressions and for changing fashions in hairstyles. To adjust in part for any potential problems 
of reverse causation, the looks of each team member are rated in the first year during the eleven-year period that his/her picture became available.

A total of 1282 pictures of top executives were rated, of which 1220 depicted men. The statistics describing the ratings of beauty are summarized in Table 1 . The results indicate that the beauty of the average top manager in the advertising industry is 2.80 , just below average on our fivepoint scale. The male executives are rated (insignificantly) less attractive than their female counterparts, a common finding in the psychology literature and consistent with previous research (e.g., Roszell et al, 1989). There is substantial agreement among raters about the top executives' looks: For the entire sample the average correlation among raters is +0.29 , and Cronbach's $\alpha$ is 0.70 . The raters' appraisals of females are more consistent than those of males: The average correlation and Cronbach's $\alpha$ are +0.39 and 0.78 , and +0.29 and 0.70 , respectively. The ratings made by the two female raters differed only slightly and insignificantly from those done by their male counterparts.

Data describing the agencies' sales and employment were also collected from the Adformatie Biilagen and the Blauwe Buropidsen. The year the agency was founded was obtained from the local Chamber of Commerce. Table 2 provides the descriptive statistics for the sample, divided into small and large firms. Small firms are agencies with fewer than 10 employees, this being the standard definition for this industry (Centraal Bureau voor de Statistiek, 1991 et seq.). During the eleven-year period many firms switched from being small to large, and a few from large to small, which explains why the number of firms in Table 2 exceeds 289 . The set of small firms consists of 718 observations on 144 agencies, while the set of large companies contains 1393 observations on 220 separate agencies. The average workforce of the small agencies is almost 7 employees, and their average sales are 1.01 million 1994 Dutch guilders (worth at that time roughly US $\$ 650$ thousand). ${ }^{7}$ The 
larger agencies have on average 27 workers, and their average sales are 4.83 million 1994 guilders. We also classify firms based on location in or outside the Randstad (the three provinces North Holland, South Holland and Utrecht, containing the major Dutch cities of Amsterdam, the Hague, Rotterdam and Utrecht).

Large agencies are somewhat older than small agencies. Not surprisingly, the growth of small firms is more erratic than that of large ones, and the probability that they die is much higher. ${ }^{8}$ Furthermore, a greater proportion of the large agencies are located in the Randstad. The importance of accounting for location is also clearly observed in the size difference between large agencies located in or outside the Randstad. The largest agencies are located in the Randstad, probably because the largest clients and suppliers are located there too. Smaller firms do business with local advertisers. While the board members of small and large firms are rated as equally attractive, for both sets of firms the agencies located outside the Randstad have worse-looking executive teams than do the agencies in the Randstad.9

\section{Beauty in the Production Function}

In this section we estimate various forms of the revenue function characterizing the set of advertising firms for which we can calculate measures of beauty capital. Because we only have data on revenue, we cannot distinguish between the alternative versions of the profit function described in equations (1) and (2). We can, however, answer the more general question, whether workers' beauty affects firms' revenues, and thus whether firms recoup the higher labor costs that previous research demonstrates are produced by better-looking workers.

We initially estimate a Cobb-Douglas type function to which a measure of the firm's beauty capital, the average beauty of the firm's board members, has been added. Also included in that basic 
function are indicator variables for the year the advertising firm is observed. The estimates of that equation are contained in the first column in Table 3. The average beauty of its executives has a positive effect on an advertising firm's revenues, as we expected.

While the estimates in column (1) are quite satisfactory, they are not robust to alternative cuts of the sample: Behavior is substantially different inside and outside the Randstad, and between small ( $<10$ employees) and large firms. We thus present estimates that include both an indicator variable for location in the Randstad and an interaction of it with the firm's average beauty in the results that follow, and we distinguish between small and large firms.

Columns (2)-(7) of Table 3 show the results of estimating the augmented production function on the (unbalanced) panel of advertising firms, first for all firms, then separately for small and large firms. Columns (2), (4) and (6) show the results for the entire sample or subsample; columns (3), (5) and (7) list estimates based on those firms for which more than one board member's picture was available, so that the standard deviation of the within-firm beauty could be calculated. The parameter estimates for the control variables accord with other facts about the industry. Considering column (2), we see that, once we account for differences between the Randstad and the rest of the country, there is a very slight degree of increasing returns to scale in this industry. This cross-section finding is consistent with the implications of evidence available since 1987 that the average firm size in the industry has increased (CBS, 1994). Given the size of the firm, having more board members generates additional revenue, presumably because board members are more motivated and more skilled than are non-board employees. Finally, sales are higher in the Randstad, other things equal. (For example, the estimates in column (2) suggest that revenues are 12 percent higher there.) This is not surprising, both because nominal prices are higher in the Randstad, and because we expect that 
more productive members of the industry will gravitate toward the area where the opportunities for advancement are greater. ${ }^{10}$

Examining columns (2), (4) and (6), we see that advertising firms with better-looking board members generate significantly greater revenues for their companies, other things equal. This is true in estimates based on the entire sample, and it is true for both small and large firms outside the Randstad. When we disaggregate the sample by location and firm size, we find that only among small firms in the Randstad is the impact of beauty on agencies' revenues negative." Why beauty should have a negative effect in this one subsample is not clear; but one possibility is that the result arises from what is essentially an artificial sample-selection problem created when we restrict the sample to small firms inside the Randstad. When firms with good-looking board members remain small in the Randstad, where the opportunities for growth are greatest (witness the interarea difference in firm size shown in Table 2), those firms presumably have unobservable characteristics that make them grow more slowly. The average small firm in the Randstad whose principals are better-looking will grow and eventually be observed in the sample of large firms. The substantial overlap of firms in the two subsamples provides some support for this. ${ }^{12}$

The average beauty of executive board members is significantly higher in the Randstad than elsewhere (2.81 compared to 2.73 , with standard error equal 0.01 ). That the returns to beauty in the Randstad (even in large firms) are lower is consistent with a movement down the marginal productivity function of beauty. Presumably there is some additional factor that is correlated with beauty and that induces better-looking executives and their firms to remain there even though the marginal returns to beauty are lower. 
If we reestimate the augmented production function separately for each of the eleven years, we find that ( $\partial \operatorname{lnSales} / \partial \mathrm{B} e a u t y)_{t}$ outside the Randstad is unchanged over time. Similarly, the average

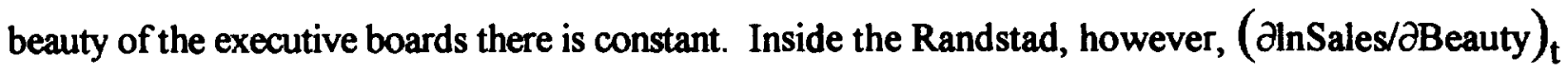
has a significant downward trend from 1984 to 1994, while the average beauty of boards in advertising firms located there rises steadily (and highly significantly). These two pairs of facts are quite consistent with rational behavior on the part of executives and their firms as they move down the function $\mathrm{f}_{\mathrm{B}}(\mathrm{N}, \mathrm{K}, \mathrm{B})$ relating beauty to productivity.

We expect that, at a constant average beauty in the firm, greater dispersion in the board members' looks will lead to greater average productivity. Greater differences in relative productivities (in this case, of beauty compared to other characteristics) generate greater opportunities for productive specialization. Although the example is somewhat stereotyped, in a firm with one goodlooking and one plain board member, the former will be hustling clients, while the latter handles financial matters in the back room. This is exactly what the estimates in columns (3), (5) and (7) of Table 3 show, both for the entire sample and for the subsamples distinguished by firm size: Greater dispersion of executives' looks raises productivity. ${ }^{13}$ Specialization -- diversity -- along the dimension of beauty pays off..$^{14}$

One might object that the estimates in Table 3 overstate the impact of beauty because we have been unable to control for unobservable productive characteristics of the board members that might be positively correlated with their looks. Lacking detailed information on the individual executives, unlike studies based on individual data (e.g., Hamermesh and Biddle, 1994) we cannot address this problem in the usual manner by obtaining detailed vectors of control variables. We can, however, 
get at part of the potential effect of unmeasured heterogeneity, since there is some intrafirm variation in the average beauty of the firm's executives (because board members are added to or dropped from the executive team over time). Thus we can account for heterogeneity in firms' characteristics by reestimating the augmented production functions using a fixed-effects estimator (adding separate constant terms for each agency). We do not expect to obtain spectacular results from this approach, since in many firms the changes in the board's composition are small. Nonetheless, this extremely strict test of the robustness of our estimates should provide some useful insights.

The (firm) fixed-effect estimates of the augmented production function are shown in Table 4 for the entire sample. Although the coefficients on the terms in beauty are not statistically significant, their magnitudes are remarkably similar to those presented in the first column of Table $3 .{ }^{15}$ A one-unit increase in average beauty raises sales by 5 percent outside the Randstad, other things equal, while inside the Randstad the impact is again positive, but much smaller than outside. The results in Table 3 thus seem quite robust.

Similarly robust to this attempt to account for a particular form of unmeasured interfirm heterogeneity is the impact of greater intrafirm heterogeneity in executives' looks. The parameter estimate on $\sigma_{\text {Besury }}$ is almost identical to its value in column (3) of Table 3 and is again significantly positive. The inference that firms can gain by working along the margins of executives' comparative advantage in the dimension of their looks does not result from our failure to account for unobserved heterogeneity among firms.

What does this evidence imply about the monetary value of beauty in this industry? More important in light of the discussion in Section I, how does the impact of beauty on the firm's value added compare to its effect on wages? Does beauty produce quasi-rents that are shared by the 
worker and the firm, or does it merely enhance the worker's productivity (and thus the firm's revenue) and wages by equal amounts? To calculate the impact on revenue we simulate the effect of changing the firm's beauty capital on the firm's sales. We consider two experiments, in each case calculated holding the other variables in the value-added equations constant: 1) The board's average beauty increases from the minimum observed in the particular subsample to the maximum; and 2) Its average looks rise from those at the tenth percentile of the distribution of agencies in the subsample to those at the ninetieth percentile.

The results of the simulations of the impact of beauty on revenue, calculated in 1994 guilders (DFL), are presented for the whole sample, by region for the entire sample, and by region for small and large firms separately, in the first two columns of Table 5 (corresponding to and based on the estimates in the seven columns of Table 3). Concentrating on the entire sample, beauty appears to be highly productive. An increase in average beauty from the tenth to the ninetieth percentile raises revenue by 21 thousand guilders per year in the Randstad and by 188 thousand guilders per year outside. For the entire sample the effect is 120 thousand guilders. Except for small firms in the Randstad, where we could not discern any positive effect of beauty on revenues, similar calculations for the other subsamples (presented in the fifth through seventh rows of the table) show that having better-looking executives generates substantially higher revenues for the agency. Of course, the impacts of moving from the minimum to the maximum beauty in each subsample are much larger.

We cannot directly infer the impact of individual board members' looks on their wages, since we do not have data on individuals' earnings. Instead, we can use extraneous estimates from studies of the impact of looks on earnings along with information on the average earnings of Dutch advertising executives to infer the responsiveness of a board member's wages, $\mathrm{W}$, to a one-unit 
change in his/her looks, $\partial \ln (\mathrm{W}) / \partial \mathrm{B}$. Multiplying this by average board size in our sample, and then multiplying by some measure of the change in beauty in the sample as one moves from less- to betterlooking boards, $\Delta \mathrm{B}$, yields:

$$
\Delta[\text { Wage Bill }] / \Delta \text { Beauty }=W \cdot[\text { Board Size }][\partial \ln (W) / \partial B] \Delta B \text {. }
$$

For comparison purposes we calculate $\Delta \mathrm{B}$ in each subsample as a move from the tenth to the ninetieth percentile of average beauty.

There are no published estimates of the average wage of agency executives for use in (3). Interviews with the deputy director of the VEA, however, suggest that in 1995 the average gross earnings of executives in its member agencies was around 225,000 guilders. ${ }^{16}$ We work with a range of 150 to 300 thousand guilders in our calculations, probably an overestimate of earnings in the whole sample given that the VEA consists of large firms. In the individual data that underlie this study (and whose characteristics are summarized in Table 1) a change in beauty from the tenth to the ninetieth percentiles moves the person from the middle of categories 1 and 2 in the ratings we have used to the middle of categories 4 and 5. Evidence from Hamermesh and Biddle (1994) and complementary results from Biddle and Hamermesh (1998) suggest that this change raises earnings in the United States by between 7.5 and 15 percent. We assume faute de mieux that the same percentage effect on earnings exists among executives in the Dutch advertising industry.

In column (3) of Table 5 we present a lower-bound estimate of $\Delta[$ Wage Bill $] / \Delta B$ Beauty, based on the assumption of a 7.5-percent effect on wages averaging 150,000 DFL per year; in column (4) we assume a 15-percent effect on average wages of 300,000 DFL per year. Except for the subsample of small firms in the Randstad, where we could not find a positive effect of beauty on revenue, in the other three subsamples, and in the entire sample as well, even the highest estimate of the impact of 
beauty on board members' earnings is far below the estimates of its effects on revenues that are implied by the regression estimates in Table 3.

While we cannot be sure, since we have no direct estimates for the Netherlands of the impact of beauty on earnings, these calculations suggest that the positive effect of executives' looks on revenues substantially exceeds the direct effects of their beauty on their own earnings. Beauty thus augments the production function, with some of the returns reflected in additional payments to those workers possessing the good looks, but another large part enhancing the value of the firm. Beauty capital yields returns, both to the worker and to the firm. While perhaps unsurprisingly much of this type of capital is not firm-specific, a large part of it appears to be. That the effect results from investments by better-looking executives' time in interactions with their work groups is consistent with our estimates. No doubt one can construct other explanations that are also consistent, but these too would have to be based on the specificity of the effects of beauty.

Table 5 also presents the effects on revenue of increasing the dispersion of beauty among a firm's executives, holding their average looks constant. The impact of moving from the minimum to the maximum (across firms) of the within-firm dispersion of beauty is quite substantial. Consistent with our explanation of this finding, we infer that there are large gains in revenue to be had from obtaining a management team with greater heterogeneity of looks and assigning the managers to different functions according to their comparative advantages along the dimensions of looks (and presumably other productive characteristics).

\section{Firm Growth}

If the returns to beauty are firm-specific and are shared by the good-looking supervisor and the firm, we should expect that this worker characteristic that creates firm-specific human capital will 
yield quasi-rents to the firm. These in turn should generate greater profits for firms possessing more of this type of capital. We do not have information on firms' profits in our sample; but with a positive impact on profits, beauty should be positively related to overall corporate performance, including the firm's rate of growth. ${ }^{17}$ Consider the transitory effect of beauty on firm performance, which can be described by:

$$
\ln \left(Y_{i t} / Y_{i t-1}\right)=G\left(\ln \left(Y_{i t-1}\right), B_{i t}, Z_{t}, \varepsilon_{i t}^{e}\right), \quad i(t)=1, \ldots, N(t), t=2, \ldots, T,
$$

where $\varepsilon_{\mathrm{it}}^{\mathrm{e}}$ is an idiosyncratic growth shock, and the vector $Z$ includes annual indicators. In estimating (4) we distinguish, as in the previous section, between small and large firms.

The estimates of (4) are presented in Table $6{ }^{18}$ They confirm that the transitory effect of beauty on businesses' growth rates is positive, more so for small firms than for large ones (consistent with the greater fluctuations in annual sales in small firms). The long-run impact of beauty can be calculated as the negative of the ratio of the coefficient of average beauty to the coefficient on $\ln \left(\right.$ Sales $\left._{-1}\right)$. These ratios, $0.19(0.07)$ for small firms inside (outside) the Randstad, $0.39(0.15)$ for large firms inside (outside), tell a story consistent with that of Section III: Even when we attempt to explain year-to-year changes in firms' revenues, we find an implicit positive long-run impact of the average beauty of their executives on their size. The impacts are statistically insignificant outside the Randstad. Inside, however, the agencies' beauty capital has a positive effect that is nearly statistically significant and that implies that a small (large) firm whose executives' looks place them at the ninetieth percentile grows 28 (19) percent more rapidly than the average such firm.

\section{Conclusions, and Implications for Ascriptive Characteristics in Production}

In this study we have used a specific example, the Dutch advertising industry, to provide the first analysis of the impact of affective human capital on firm performance. Like other characteristics, 
such as sex and race, the affective characteristic upon which we have focused -- a worker's beauty -is one that a number of studies have recently demonstrated to have an effect on earnings. Like earnings differentials associated with sex and race, it is not clear a priori whether and to what extent differentials associated with beauty are due to discrimination or to differences in productivity. Our strategy of examining the impact of employees' beauty on firms' revenues and growth has allowed us to shed light on that question. It demonstrates that studies that consider the impact of workers' other ascriptive characteristics on firms' performance would provide a useful complement to the vast literature that simply measures the wage differences associated with those characteristics.

Our results indicate that greater employee beauty is in most circumstances associated with higher revenues. Our estimates also suggest that the increases in revenue almost certainly exceed the higher labor costs associated with hiring more attractive employees, implying that employees' beauty enhances their firms' profitability. Consistent with this evidence, we find a positive relationship between employees' beauty and firm growth.

There are clearly limits to the generalizability of these results. What is true of beauty may not be true of all worker characteristics; and what is true of beauty's effects in Dutch advertising may not be true of its impact in other industries or in other places. What is generalizable is our approach, which considers workers' characteristics as endowments that, like native intelligence, lower the cost to them of acquiring a certain kind of human capital. The specificity of the human capital associated with beauty may produce a situation in which firms and workers bargain over the returns to that capital. Workers' other characteristics may be associated with more or less specific forms of human capital. Our results suggest that there might be a substantial payoff to paying more attention to the 
heterogeneity of the labor input, and to the mechanisms and processes through which differences in workers' characteristics are translated into differences in firms' productivity and profitability. 


\section{REFERENCES}

David Audretsch and Talat Mahmood, "New Firm Survival: New Results Using a Hazard Function," Review of Economics and Statistics, 77 (1995): 97-103.

Gary Becker, Human Capital. New York: Columbia University Press, 1964.

Jeff Biddle and Daniel Hamermesh, "Beauty, Productivity and Discrimination: Lawyers' Looks and Lucre," Joumal of Labor Economics, 15 (1998), forthcoming.

Ray Bull and Nichola Rumsey, The Social Psychology of Facial Appearance. New York: Springer, 1988.

Ronald Burt, Structural Holes. Cambridge: Harvard University Press, 1992.

James Cagley, "A Comparison of Advertising Agency Selection Factors: Advertiser and Agency Perceptions," Journal of Advertising Research, 26 (1986): 39-44.

Centraal Bureau voor de Statistiek, Onder de Loep Genomen: Reklame- en Advertentiebureaus, various issues. Heerlen, the Netherlands: CBS, 1991 et seq.

Commission of the European Community, Panorama of EC Industries 1993. Brussels: EC, 1994.

FHV/BBDO. The Selection Process of Advertising Agencies and Implications for a New-Business Policy. Amsterdam: Club of 13, 1983.

Randall Filer, "The Influence of Affective Human Capital on the Wage Equation," Research in Labor Economics, 4 (1981): 367-409.

Daniel Hamermesh and Jeff Biddle, "Beauty and the Labor Market," American Economic Review, 84 (1994): 1174-94.

Masanori Hashimoto, "Firm-Specific Human Capital as a Shared Investment," American Economic Review, 71 (1981): 475-82.

and B. T. Yu, "Specific Capital, Employment Contracts and Wage Rigidity," Bell Loumal of Economics, 2 (1980): 536-49.

Elaine Hatfield and Susan Sprecher, Mirror. Mirror... The Importance of Looks in Everyday Life. Albany: SUNY Press, 1986.

Carl Hiaasen, Striptease. New York: Warner, 1993. 
W. Bruce Johnson, Robert Magee, Nandu Nagarajan and Harry Newman, "An Analysis of the Stock Price Reaction to Sudden Executive Deaths: Implications for the Managerial Labor Market," Lournal of Accounting and Economics, 7 (1985): 151-74.

Lee Lillard, "The Market for Sex: Street Prostitution in Los Angeles," Unpublished Paper, RAND Corporation, 1995.

Patricia Roszell, David Kennedy and Edward Grabb, "Physical Attractiveness and Income Among Canadians," Journal of Psycholosy, 123 (1989): 547-59.

Jerold Warner, Ross Watts and Karen Ruck, "Stock Prices, Event Prediction and Event Studies: An Examination of Top Management Changes," Journal of Financial Economics, 20 (1988): 461-92.

Finis Welch, "Education in Production," Journal of Political Economy, 78 (1970): 764-71. 
Table 1. Statistics Describing the Ratings of Beauty

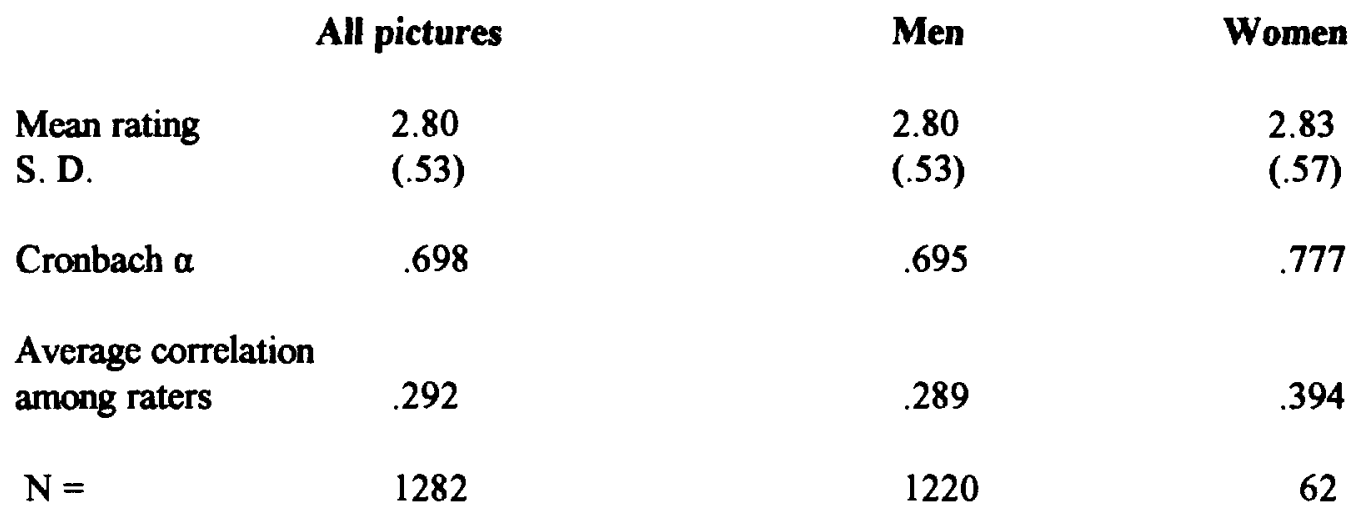


Table 2. Means and Standard Deviations of Major Variables

All Firms $\quad$ Small Firms*

\begin{tabular}{|c|c|c|c|c|c|c|c|}
\hline Variable & & All & Randstad & Other & All & Randstad & Other \\
\hline $\begin{array}{l}\text { Sales } \\
(10001994 \mathrm{DFL})\end{array}$ & $\begin{array}{c}3542 \\
(4530)\end{array}$ & $\begin{array}{l}1012 \\
(471)\end{array}$ & $\begin{array}{l}1056 \\
(489)\end{array}$ & $\begin{array}{c}923 \\
(420)\end{array}$ & $\begin{array}{c}4831 \\
(5093)\end{array}$ & $\begin{array}{c}5451 \\
(5585)\end{array}$ & $\begin{array}{c}2737 \\
(1593)\end{array}$ \\
\hline$\Delta \ln$ (Sales) & $\begin{array}{r}.051 \\
(.193)\end{array}$ & $\begin{array}{l}.049 \\
(.211)\end{array}$ & $\begin{array}{l}.049 \\
(.222)\end{array}$ & $\begin{array}{c}.051 \\
(.192)\end{array}$ & $\begin{array}{l}.051 \\
(.184)\end{array}$ & $\begin{array}{l}.046 \\
(.184)\end{array}$ & $\begin{array}{l}.067 \\
(.183)\end{array}$ \\
\hline $\operatorname{Pr}\{$ Firm Death $\}$ & .143 & .240 & .226 & .267 & .095 & .092 & .102 \\
\hline Employment & $\begin{array}{c}19.99 \\
(20.25)\end{array}$ & $\begin{array}{l}6.63 \\
(1.78)\end{array}$ & $\begin{array}{c}6.64 \\
(1.75)\end{array}$ & $\begin{array}{c}6.62 \\
(1.85)\end{array}$ & $\begin{array}{l}26.74 \\
(21.91)\end{array}$ & $\begin{array}{r}29.32 \\
(23.96)\end{array}$ & $\begin{array}{l}17.91 \\
(7.54)\end{array}$ \\
\hline $\begin{array}{l}\text { No. of Board } \\
\text { Members }\end{array}$ & $\begin{array}{c}2.82 \\
(1.72)\end{array}$ & $\begin{array}{l}1.82 \\
(.83)\end{array}$ & $\begin{array}{l}1.96 \\
(.86)\end{array}$ & $\begin{array}{l}1.55 \\
(.68)\end{array}$ & $\begin{array}{c}3.31 \\
(1.84)\end{array}$ & $\begin{array}{l}3.50 \\
(1.94)\end{array}$ & $\begin{array}{c}2.63 \\
(1.19)\end{array}$ \\
\hline Randstad & .740 & .666 & & & .778 & & \\
\hline Age of Firm & $\begin{array}{r}19.76 \\
(19.74)\end{array}$ & $\begin{array}{c}14.40 \\
(12.40)\end{array}$ & $\begin{array}{c}16.18 \\
(13.39)\end{array}$ & $\begin{array}{l}10.73 \\
(9.06)\end{array}$ & $\begin{array}{c}22.42 \\
(22.03)\end{array}$ & $\begin{array}{c}23.55 \\
(23.87)\end{array}$ & $\begin{array}{c}18.34 \\
(12.59)\end{array}$ \\
\hline Beauty & $\begin{array}{c}2.79 \\
(.37)\end{array}$ & $\begin{array}{l}2.79 \\
(.45)\end{array}$ & $\begin{array}{l}2.82 \\
(.48)\end{array}$ & $\begin{array}{c}2.72 \\
(.37)\end{array}$ & $\begin{array}{c}2.79 \\
(.33)\end{array}$ & $\begin{array}{l}2.80 \\
(.34)\end{array}$ & $\begin{array}{l}2.74 \\
(.30)\end{array}$ \\
\hline$\sigma_{\text {Beauty }}$ & $\begin{array}{c}.49 \\
(.25)\end{array}$ & $\begin{array}{c}.47 \\
(.28)\end{array}$ & $\begin{array}{c}.48 \\
(.27)\end{array}$ & $\begin{array}{c}.42 \\
(.29)\end{array}$ & $\begin{array}{c}.49 \\
(.24)\end{array}$ & $\begin{array}{c}.50 \\
(.24)\end{array}$ & $\begin{array}{r}.46 \\
(.23)\end{array}$ \\
\hline $\mathbf{N}$ & 2111 & 718 & 478 & 240 & 1393 & 1074 & 319 \\
\hline $\mathrm{N}$ firms & 289 & 144 & 98 & 47 & 220 & 170 & 54 \\
\hline
\end{tabular}

small firms have fewer than 10 employees.

\section{Large Firms}

Randstad Other

$\begin{array}{lcc}.051 & .046 & .067 \\ (.184) & (.184) & (.183)\end{array}$

$\begin{array}{lll}26.74 & 29.32 & 17.91\end{array}$

(21.91) (23.96) (7.54)

$\begin{array}{lll}3.31 & 3.50 & 2.63\end{array}$

.778

$\begin{array}{lll}22.42 & 23.55 & 18.34\end{array}$

$\begin{array}{lll}2.79 & 2.80 & 2.74\end{array}$

(.33) (.34) (.30)

$\begin{array}{lrr}.49 & .50 & .46 \\ (.24) & (.24) & (.23)\end{array}$

$1393 \quad 1074 \quad 319$

54 
Table 3. The Effect of Beauty on Productivity (Dependent Variable $=\ln ($ Sales))

Variables

$\ln$ (Employees)

$\ln$ (Board)

Beauty

Randstad

Beauty*Randstad

$\sigma_{\text {Beauty }}$

Year dummies

Firm dummies

$\overline{\mathbf{R}}^{2}$

$\mathbf{N}$

$\mathrm{N}$ firms

$\partial \ln ($ Sales $) / \partial$ Beauty in Randstad
All Firms

$$
\begin{array}{ccc}
.750 & 1.046 & 1.051 \\
(.011) & (.011) & (.013)
\end{array}
$$

$\begin{array}{lll}.116 & .105 & .142\end{array}$

(.016) (.016) (.024)

$\begin{array}{lll}.038 & .115 & .187\end{array}$

(.018) (.041) (.059)

$$
\begin{array}{ll}
.412 & .856 \\
(.128) & (.175)
\end{array}
$$

$\begin{array}{ll}-.110 & -.268\end{array}$

(.046) (.064)

.089

(.031)

yes yes yes

no no no

$\begin{array}{lll}.876 & .878 & .892\end{array}$

$\begin{array}{lll}2107 & 2107 & 1497\end{array}$

$289 \quad 289$

235

$\begin{array}{ll}.005 & -.080\end{array}$

(.022) (.025)
Small Firms

$\begin{array}{cc}.844 & .766 \\ (.044) & (.054)\end{array}$

$.078 \quad .287$

(.031) (.066)

$\begin{array}{ll}.125 & .192\end{array}$

(.064) (.120)

$\begin{array}{ll}.672 & 1.237\end{array}$

(.200) (.342)

$\begin{array}{ll}-.203 & -.399\end{array}$

(.072) (.125)

.088

(.032)

yes yes

no no

$.399 \quad .461$

$714 \quad 370$

$144 \quad 93$

$\begin{array}{ll}-.078 & -.207\end{array}$

(.034) (.038)
Large Firms

$1.104 \quad 1.115$

(.015) (.016)

$.108 \quad .090$
0

(.017) (.025)

$.175 \quad .259$

(.055) (.065)

\begin{tabular}{ll}
$.321 \quad .601$ \\
\hline
\end{tabular}

(.168) (.201)

$\begin{array}{ll}-.083 & -.185\end{array}$

(.061) (.074)

.033

(.035)

yes yes

no no

$.853 \quad .867$

$1393 \quad 1127$

$220 \quad 192$

\begin{tabular}{ll}
$.092 \quad .074$ \\
\hline
\end{tabular}

(.027) (.034) 
Table 4. Fired-Effects Estimates of the Productivity Equation, All Firms (Dependent Variable = In(Sales))

\begin{tabular}{|c|c|c|}
\hline Variables & & \\
\hline $\ln$ (Employees) & $\begin{array}{l}0.718 \\
(.019)\end{array}$ & $\begin{array}{l}0.761 \\
(.022)\end{array}$ \\
\hline $\ln$ (Board) & $\begin{array}{l}.049 \\
(.014)\end{array}$ & $\begin{array}{l}.031 \\
(.020)\end{array}$ \\
\hline Beauty & $\begin{array}{c}.052 \\
(.052)\end{array}$ & $\begin{array}{r}.042 \\
(.088)\end{array}$ \\
\hline Randstad & $\begin{array}{l}.196 \\
(.167)\end{array}$ & $\begin{array}{r}.242 \\
(.259)\end{array}$ \\
\hline Beauty*Randstad & $\begin{array}{l}-.037 \\
(.060)\end{array}$ & $\begin{array}{l}-.048 \\
(.095)\end{array}$ \\
\hline$\sigma_{\text {Beauty }}$ & & $\begin{array}{l}.096 \\
(.037)\end{array}$ \\
\hline Year dummies & yes & yes \\
\hline Firm dummies & yes & yes \\
\hline$\overline{\mathbf{R}}^{2}$ & .960 & .964 \\
\hline $\mathbf{N}$ & 2107 & 1497 \\
\hline $\mathrm{N}$ firms & 289 & 235 \\
\hline $\begin{array}{l}\partial \ln (\text { Sales)/ } / \partial \text { Beauty } \\
\text { in Randstad }\end{array}$ & $\begin{array}{l}.015 \\
(.028)\end{array}$ & $\begin{array}{l}-.006 \\
(.035)\end{array}$ \\
\hline
\end{tabular}


Table 5. The Effect of Changing Beauty on Sales and Wages (in thousand 1994 DFL)

Effect on:

Sales

\section{AAverage Beauty:}

$$
\operatorname{Min}-\operatorname{Max}
$$

10 th $\rightarrow 90$ th
Percentile

$\begin{array}{ll}\text { 10th } \rightarrow 90 \text { th } & \text { 10th } \rightarrow 90 \text { th } \\ \text { Percentile } & \text { Percentile } \\ (\mathrm{W}=150 \mathrm{~K} \text { DFL } & (\mathrm{W}=300 \mathrm{~K} \text { DFL } \\ \partial \ln (\mathrm{W}) / \partial \mathrm{B}=.075) & \partial \ln (\mathrm{W}) / \partial \mathrm{B}=.15)\end{array}$

119.6

20.5

188.3

365.0

Other

Small Firms

$$
\text { Randstad }
$$

Other

Large Firms

Randstad

Other

297.4

49.7

$-199.2$

186.7

$-93.4$

115.5

16.6

11.6

46.5

66.6 
Table 6. Firm Growth

\begin{tabular}{|c|c|c|c|}
\hline & All firms & Small firms & Large firms \\
\hline $\ln \left(\right.$ Sales.1. $\left.\left._{-1}\right)\right)$ & $\begin{array}{l}-.031 \\
(.004)\end{array}$ & $\begin{array}{l}-.124 \\
(.016)\end{array}$ & $\begin{array}{l}-.053 \\
(.006)\end{array}$ \\
\hline Beauty & $\begin{array}{l}-.011 \\
(.023)\end{array}$ & $\begin{array}{l}.009 \\
(.034)\end{array}$ & $\begin{array}{l}.008 \\
(.031)\end{array}$ \\
\hline Randstad & $\begin{array}{l}-.083 \\
(.072)\end{array}$ & $\begin{array}{l}-.033 \\
(.107)\end{array}$ & $\begin{array}{l}-.040 \\
(.096)\end{array}$ \\
\hline Beauty $*$ Randstad & $\begin{array}{c}.029 \\
(.026)\end{array}$ & $\begin{array}{l}.015 \\
(.039)\end{array}$ & $\begin{array}{l}.013 \\
(.035)\end{array}$ \\
\hline Year dummies & yes & yes & yes \\
\hline$\overline{\mathbf{R}}^{2}$ & .135 & .198 & .162 \\
\hline $\mathbf{N}$ & 2085 & 701 & 1384 \\
\hline $\mathrm{N}$ firms & 289 & 140 & 220 \\
\hline $\begin{array}{l}\partial\{\Delta \operatorname{lnSales}\} / \partial \text { Beauty } \\
\text { in Randstad }\end{array}$ & $\begin{array}{l}.018 \\
(.012)\end{array}$ & $\begin{array}{l}.024 \\
(.018)\end{array}$ & $\begin{array}{l}.021 \\
(.015)\end{array}$ \\
\hline
\end{tabular}




\section{FOOTNOTES}

1. See Hamermesh and Biddle, 1994; and for specific groups of workers, such as attorneys, see Biddle and Hamermesh (1998) and for prostitutes, see Lillard (1995).

2. The difference in quality would have to be real, not simply a perception on the part of some clients, for clients paying higher prices for advertising based on a misperception could not survive in a competitive environment.

3. This line of argument suggests that it is in part the social skills of the more attractive, as opposed to attractiveness per se, that enhance their greater productivity. Certainly social skills, or at least some proxies for them, appear to increase wages (Filer, 1981). But if, as some researchers hypothesize, these greater social skills develop as a result of positive reactions people receive from others in social situations from childhood on, then attractiveness is the ultimate cause of the greater productivity. This is expressed most eloquently by Hiaasen (1993), "Erin was still naive enough to believe that all crooks had bad teeth, greasy hair and jailhouse tattoos. She assumed that clean-cut, good-looking men possessed the same natural advantage as clean-cut, good-looking women: The world treated you better, and consequently there was no reason for unwholesome behavior."

4. The Rota is an association where agencies are registered on request but are accepted only if they fulfill several requirements for qualitative and financial stability. Rota registration was considered indicative of a qualitatively and financially viable agency. The VEA (Yerenigine voor erkende reklame-adviesbureaus) and the Pragma are industry associations. The former represents the interests of the larger agencies, while the latter represents smaller agencies.

5. The extremely large number of smaller agencies not included in the sample (about 9000 , as enumerated by the Centraal Bureau voor de Statistiek, CBS, 1994) cannot be considered true advertising agencies, as they consist mainly of free-lance workers, studios and all sorts of small specialists. While the CBS data include many different and noncompeting markets, our sample is composed of direct competitors only and therefore gives a better indication of the advertising agencies operating in the Netherlands than the data provided by the CBS.

6. Zeer knap; boven gemiddeld mooi; gemiddeld uiterliik; minder dan gemiddeld mooi; and leliik.

7. Sales refer to the income of the agency after suppliers and other third parties have been paid, so that we use the terms sales and value-added interchangeably.

8. The slightly higher average growth rate among large firms is the artifact of basing the sample definition on current employment. Those small firms that grow rapidly -- that are successful -- soon become large firms and leave the subsample.

10. This difference does not arise because of local biases of the people who rated the pictures, since most of them lived outside the Randstad.

10. We also experimented with a variable that accounts for different kinds of advertising products. Including this measure had little impact on the estimates. Similarly, an indicator variable of whether the agency was controlled by some international firm did not alter the conclusions qualitatively. 
11. The two basic equations presented here were all reestimated with a continuous measure of employment rather than the small firm-large firm distinction, and with that measure interacted with region. The basic results -- that there are significant positive effects of beauty on revenue in large agencies throughout the Netherlands, and in small agencies outside the Randstad -- were unaltered by this alternative approach.

12. In the subsamples for which information was available we added a measure of the firm's age to these regressions. This modification in no way changed the qualitative implications of the estimates in Table 3. The underlying source also provided information on the nature of the firms' major customers. Regrettably the classification was such that the customers of over $3 / 4$ of the agencies were classified as "other," making this measure of little use for examining the impact of customer type on the effect of beauty.

13. An alternative hypothesis is that it is the beauty of the best-looking executive that raises firms' revenue the most (and generates any quasi-rents that may arise). To examine this possibility we replaced $\sigma_{\text {Benuty }}$ by a measure of the maximum beauty of firms' executives. This measure always had less explanatory power and, indeed, in one case a negative coefficient. The notion of workers being assigned according to their comparative advantage, with beauty being one dimension of comparative advantage, is more consistent with the data.

14. The equations presented in Table 3 do not include interactions of $\sigma_{\text {Beeuty }}$ with the indicator for location in the Randstad. The coefficients on those interactions are very small, with t-statistics well below 0.5 , and their inclusion does not qualitatively alter any of the coefficients listed in the Table.

15. A Wu-Hausman test of the constancy of the parameters between the two sets of estimates fails to reject the hypothesis that they are the same.

16. Interview with Frans Blanchard, November 5, 1996.

17. Audretsch and Mahmood (1995) find that firm-specific characteristics, such as ownership structure and initial conditions, play a substantial role in the likelihood of success.

18. The significance and sign of the estimates of $\partial \Delta \ln ($ Sales $) / \partial B$ Beauty are unaffected if we exclude $\ln ($ Sales. 1). 